Meta

Journal des traducteurs

Translators' Journal

\title{
Introductory Note to the Special Issue of Meta on Poetic Translation
}

\section{Daniel Slote}

Volume 23, numéro 1, mars 1978

La traduction poétique

URI : https://id.erudit.org/iderudit/004187ar

DOI : https://doi.org/10.7202/004187ar

Aller au sommaire du numéro

Éditeur(s)

Les Presses de l'Université de Montréal

ISSN

0026-0452 (imprimé)

1492-1421 (numérique)

Découvrir la revue

Citer ce document

Slote, D. (1978). Introductory Note to the Special Issue of Meta on Poetic

Translation. Meta, 23(1), 5-6. https://doi.org/10.7202/004187ar d'utilisation que vous pouvez consulter en ligne.

https://apropos.erudit.org/fr/usagers/politique-dutilisation/ 


\section{Introductory Note to the special issue of Meta on Poetic Translation}

Some bore pointed out to me recently that \& poet $\gg$ is a four-letter word. A mindless remark but a typical one. We have come a long but not better way from the Greeks where the poet was a seer and a hero. Since then he has had his brief moments of glory through the ages but it was the nineteenth century in France that tried its best to reinstate the poet, to place him above or outside of society and its ephemera : the attempt only succeeded in making him peripheral in the negative sense. What we, in our own century, have kept of the poet's role is just that : around, about, over, above, but seldom in life in any truly relevant way.

Of course there are readings by poets of their poetry. Of course books of poetry are published. Of course some of us read poetry, even at night, to friends, with the curtains drawn. But those persons are few ; and the few are not always happy; others throw things to show what they think of a tedious elite, suspect at the best, nutty at the worst. But it does not matter in the least. The pendulum swings. Another age will look more gently, perhaps, on the poet and his wordsculptures.

What is important is the fact that in our technologically-oriented society some persons have not only continued to read and write poetry, but to translate it. Not for money. Not for power. But for poetry itself.

This special issue of Meta groups some of those persons. They all, each in his or her own very special way, have a love of poetry which has induced them to try to transfer into one language the light and music they experienced in another, and in most cases, foreign culture.

The range is impressive : we shift back and forth in time from Homer to Brauquier and from Machaut to Auden and to songs composed a few years ago. What strikes me most in this series of articles is the fact that each translator of poetry presents a universe, intensely felt and intensely real, that is different in profound ways from the universe of another author. The differences converge at one point only : the intersection of language and tension we recognize as poetry.

One is left with the impression that this is as it should be ; that poetry has an infinity of faces and that each one has its own beauty to be contemplated in its own light, from as many different angles as there are admirers. 
META XXIII, 1

Another aspect that struck we as I compiled these articles was the absence of dogma and rules; in spite of certain concepts which overlap from one writer to the next, the ultimate "message » seems to be that here is no magic formula for translating poetry and that the most successful translations have been done by good writers who happen to be good translators as well.

DANIEL SLOTE 